\begin{abstract}
要旨
症例は 76 歳, 男性. 他疾患精査中の胸部 X 線単純写真で異常陰影を指摘された. 胸部 CT および MRIにおいて, 肺と縦 隔に広く接する $6 \mathrm{~cm}$ 大の腫瘤影を認めた. extrapleural sign 陽性であり, 微細石灰化, 脂肪成分の存在が示唆された。縦隔 奇形腫を疑い手術を行ったところ，腫瘤は右下葉から発生し肺外に突出するように発育する腫瘍性病变であった。下肺静脈 に近接していたため部分切除は困難と判断し，右下葉切除術を行った．術後の病理診断により肺過誤腫の診断を得た．肺過 誤腫は肺良性腫瘍の中で最も頻度が高く，比較的なじみのある疾患である．今回，特異的な発育形態と局在から，術前に縦 隔腫瘍と診断された症例を経験した，稀ではあるものの類似の報告例もみられ，教訓的であると思われたので，文献的考察 を加えて報告する.
\end{abstract}

索引用語 : 肺過誤腫, 縦隔腫瘍, extrapleural sign pulmonary hamartoma, mediastinal tumor, extrapleural sign

はじめに

肺過誤腫は，肺から発生する良性腫瘍の中で最も頻度 の高い疾患である ${ }^{1)}$. 末梢発生が約 9 割を占め ${ }^{2)}$, 無症状の 単発結節影として発見されることが多い.

今回我々は，右下葉に発生し肺外に突出するように発 育し, 術前の画像所見から縦隔腫瘍と診断された肺過誤 腫の 1 例を経験したので報告する.

\section{症例}

症 例 : 76 歳, 男性.

主 訴: 他疾患観察中の胸部 X 線異常陰影.

喫煙歴：なし.

家族歴：特になし.

既往歴：高血圧症, 糖尿病.

現病歴：他疾患観察中の胸部単純 X 線写真で異常陰 影を指摘され, 精查目的で当院呼吸器内科紹介となった. 胸部 CT, 胸部 MRI の所見から縦隔腫瘍が疑われた。外

佐世保市立総合病院呼吸器外科

原稿受付 2014年 8 月14日

原稿採択２014年10月24日
科的切除を考慮され，当科紹介となった．

入院時現症：身長 $159 \mathrm{~cm}$, 体重 $64 \mathrm{~kg}$. 表在リンパ節は 触知せず，呼吸音は清. Performance status：0, HughJones 呼吸機能分類：I 度.

入院時検查所見：HbAlc 7.0\% と高值を示した。腫瘍 マーカーは, SCC $1.7 \mathrm{ng} / \mathrm{ml}$, 可溶性 IL-2 受容体 $631 \mathrm{U} / \mathrm{ml}$ と軽度高值であったが, それ以外は正常範囲内であった。

胸部単純 $X$ 線検査 (Fig. 1)：右下肺野に境界明瞭, 辺 縁平滑な $5 \mathrm{~cm}$ 大の腫瘤影を認めた。

胸部 CT 所見（Fig. 2)：下肺静脈尾側縁，椎体，下大 静脈に接する $6.0 \times 5.0 \times 4.8 \mathrm{~cm}$ 大, 境界明膫, 辺縁平滑な 腫瘤影を認めた．水平断では extrapleural sign を認め た. 内部は不均一で, 辺縁を中心に造影効果を示した。 また, 点状の高吸収巣を認め, 微細石灰化の存在が示唆 された。

胸部 MRI 所見（Fig. 3）：T1 サブトラクション画像に おいて脂肪成分の存在が示唆された

以上の所見から，縦隔奇形腫を疑った．診断と治療を 目的として手術を行う方針とした.

手術所見（Fig. 4）：胸腔内を観察すると, 病変は右下 葉から発生し, 肺外に突出するように発育する腫瘍で あった，穿刺吸引細胞診では，診断に寄与する有意な所 


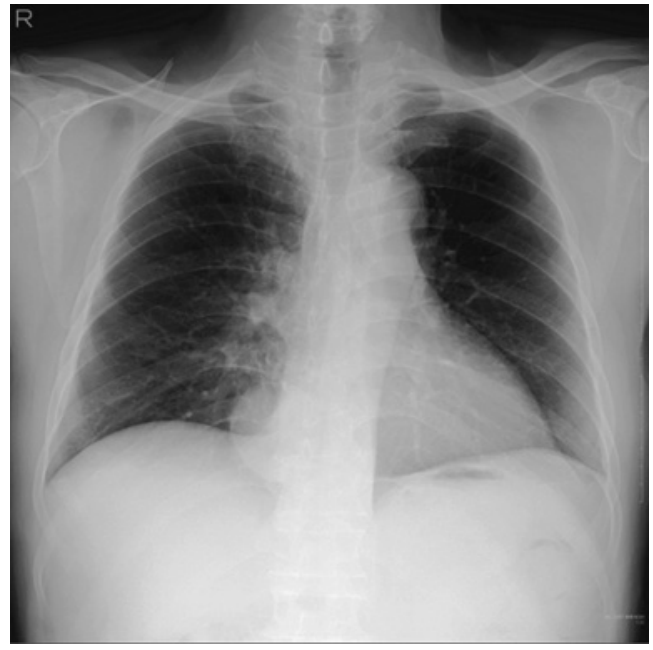

Fig. 1 Chest radiograph shows a tumor shadow of approximately $5 \mathrm{~cm}$ in diameter to the right of the mediastinum.

見は得られなかった，腫瘍のサイズが大きく，下肺静脈 に広く接しており部分切除が困難であったため, 右下葉 切除およびリンパ節郭清 (ND1b)を施行した. 術中迅速 組織診断は行わなかった.

病理組織所見（Fig. 5)：腫瘍は，肺組織および胸膜結 合織に囲まれ，肺内腫瘍と考えられた，大小多くの軟骨 成分および脂肪織，粘液様組織など複数の間葉系組織を 認め，線毛上皮が不規則に管状分岐状に増生しているこ とから肺過誤腫と診断された.

術後経過：合併症なく経過し, 術後 8 日目に自宅退院 となった。

考察

過誤腫は, 1904 年 Albrechtによりはじめて提唱され た疾患概念であり，発生した臟器の正常組織を構成する 諸要素が異常な量と割合で塊を形成したものと定義され だ)。しかしながら，組織学的に未熟な間葉系細胞が含ま れることや，遺伝子異常がしばしばみられることなどか ら, 現在では新生物と考えられている5).

肺良性腫瘍の中では最も頻度が高く，剖検材料を用い た報告によると, 全人口の $0.025 \sim 0.32$ パーセントに生じ るという ${ }^{6}$.また，末梢発生が大部分を占め，中枢気管支 発生は抄よそ $10 \%$ と報告されている ${ }^{2)}$. 大きさについて は，教科書的には $4 \mathrm{~cm}$ を超えないとされるが7)，それ以 上のサイズの報告も散見される゙.

特徵的な画像所見として，石灰化や脂肪成分を含むこ
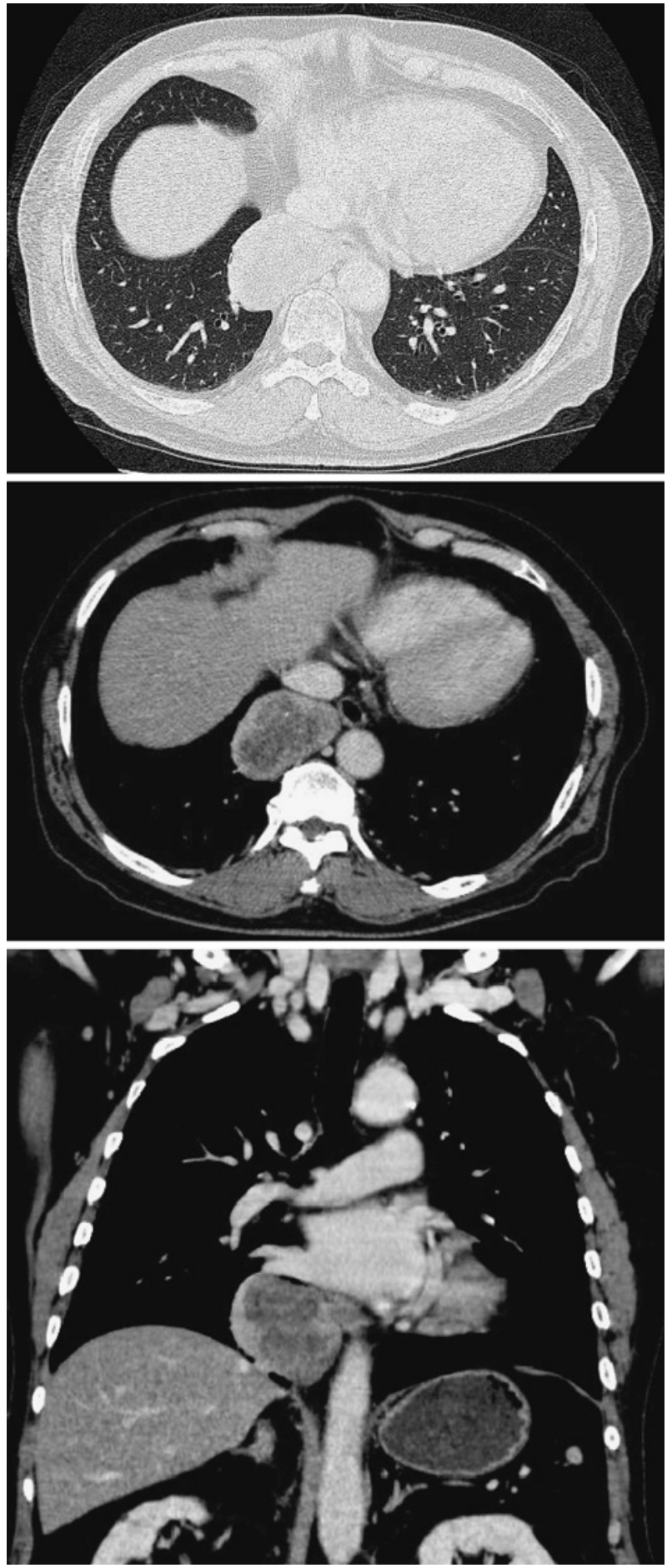

Fig. 2 Chest CT showing a mass of $6 \mathrm{~cm}$ in diameter, with calcification. The mass exhibits an extrapleural sign.

とが知られているが, それらの所見の頻度は 10～30\% と それ程高くはない99. しばしば肺悪性腫瘍やその他の肺良 性腫瘍との鑑別を要するが，通常気管支鏡や CT ガイド 


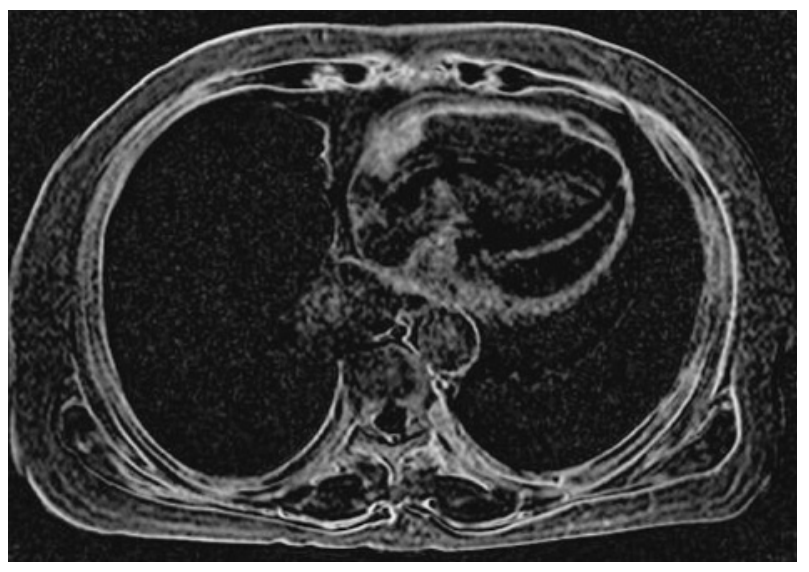

Fig. 3 Chest MRI findings indicate a mass lesion with adipose tissue.

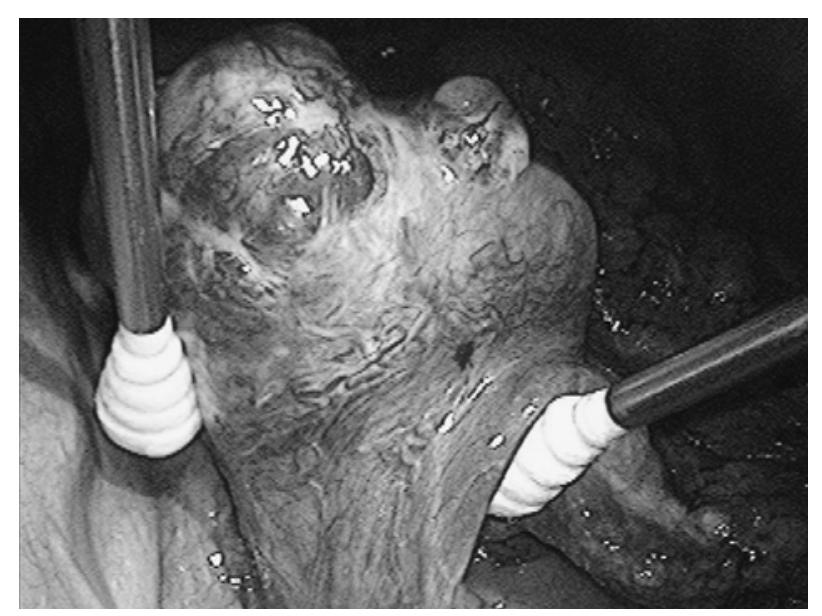

Fig. 4 Operative findings demonstrating a solid tumor located in the right lower lobe.

下生検で組織学的確定診断を得ることは困難である。 そ のため, 治療と診断を兼ねて外科的切除の適応となるこ とが多い。術中に確定診断が得られれば, 再発や悪性転 化は極めて稀であり，核出術や部分切除が妥当である。

本症例において, 腫瘍は臟側胸膜および肺組織に被覆 される肺内病変であったが, 肺外に突出する特異な進展 形式を示し, 縦隔側に広く接していたため, 画像上 extrapleural sign を認めたものと考えられる. extrapleural sign は, Felsonにより提唱され ${ }^{10)}$, 病変が肺外にあるこ とを示唆する所見である. extrapulmonary sign とも呼 ばれる，ただし，偽陰性や偽陽性には注意が必要であり， 特に縦隔側の病変については, 肺内, 肺外の鑑別に有用 とは言えないことがしばしばあるとされている ${ }^{11)}$ これ

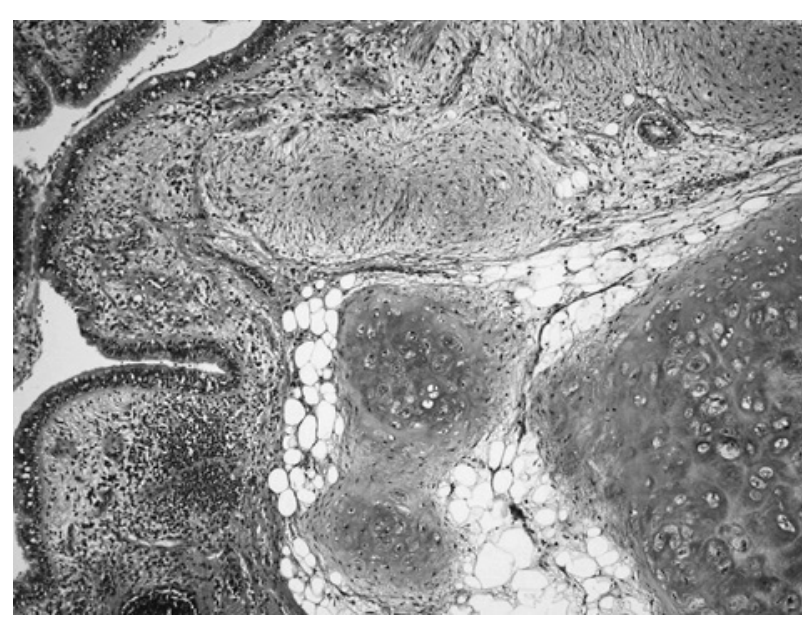

Fig. 5 Histopathological findings: The tumor consists of ciliated columnar epithelium, cartilage, and adipose tissue (Hematoxylin and eosin stain, $\times 100$ ).

までに，本邦において縦隔腫瘍との鑑別が困難であった 肺過誤腫の報告例は 2 件あり, いずれも腫瘍は肺外に突 出するように発育し, 縦隔側のポケット状の空間に存在 したため, extrapleural sign を呈していた ${ }^{12,13}$. 本症例を 含めて, 術前の画像所見において, 肺過誤腫を含む肺由 来の病変を鑑別に挙げることは困難であると思われた。

\section{結語}

肺外に突出するように発育し, 縦隔と広く接していた ことから，術前に縦隔腫瘍と診断された肺過誤腫の 1 例 を経験した，肺と縦隔に広く接する病変の場合， extrapleural sign は偽陽性となることがしばしばあることを 念頭に置き, 縦隔由来の病変, 胸膜由来の病変と共に肺 由来の病変を鑑別診断に加えた上で, 診断および治療方 針を検討することが肝要である.

\section{謝辞}

最後に病理組織学的診断にご尽力頂いた，佐世保市立 総合病院病理診断科 岩崎啓介先生に深謝致します.

\section{利 益相 反}

本論文について申告する利益相反はない.

$$
\text { 文献 }
$$

1. 正岡 昭, 藤井義敬, 矢野智紀, 佐々木秀文. 5. その他 の肺腫瘍. 藤井義敬編. 呼吸器外科学. 改訂 4 版. 東京 : 
南山堂 ; 2009: 258-9.

2. Van den Bosch JM, Wagenaar SS, Corrin B, Elbers JR, Knaepen PJ, Westermann CJ. Mesenchymoma of the lung (so called hamartoma): a review of 154 parenchymal and endobronchial cases. Thorax 1987; 42: 790-3.

3. 高原太郎. 脂肪抑制法. 高橋光幸, 中村理宣, 北川 久, 堀江朋彦編. MRI 応用自在. 第 3 版. 東京: メジカル ビュー社；2013: 111-5.

4. Albrecht E. Ueber Hamartome. Verh Dtsch Path Ges 1904; $7: 153$.

5. Kazmierczak B, Meyer-Bolte K, Tran KH, Wöckel W, Breightman I, Rosigkeit J, et al. A high frequency of tumors with rearrangements of genes of the HMGI (Y) family in a series of 191 pulmonary chondroid hamartomas. Genes Chromosomes Cancer 1999; 26: 125-33.

6. Gjevre JA, Myers JL, Prakash UB. Pulmonary hamartomas. Mayo Clin Proc 1996; 71: 14-20.

7. Ludwig C, Passlick B, Stoelben E. Recurrent hamartoma at the trocar incision site after video-assisted thoracic surgical resection. J Thorac Cardiovasc Surg 2005; 130:
609-10.

8. Ribet M, Jaillard-Thery S, Nuttens MC. Pulmonary hamartoma and malignancy. J Thorac Cardiovasc Surg 1994; 107: 611-4.

9. 桐生拓司, 川口真平, 岩田 尚, 小久保光弘, 下川邦泰, 松永研吾, 他.【胸部の最新画像情報 2007】末梢肺癌との 鑑別が困難で切除された良性孤立肺結節病変の画像所見 の検討. 臨放 2007; 52: 150-66.

10. Felson B. Chest Roentgenology. Philadelphia: W.B. Saunders; 1973

11. 林 邦昭. 第 2 章 読影のための基本事項. 林 邦昭, 中 田肇編. 新版 胸部単純 $\mathrm{X}$ 線診断 画像の成り立ちと 読影の進め方. 東京 : 秀潤社 ; 2000: 51-2.

12. 原 拓央, 太田安彦, 太田尚宏, 平沼知加志, 渡辺俊一, 小田 誠, 他. 肺外性進展を来し, 縦隔腫痬との鑑別が困 難であった巨大肺過誤腫の 1 例. 日呼外会誌 $2001 ; \mathbf{1 5}$ : $590-4$.

13. 山崎庸弘, 金子公一, 石田博徳, 坂口浩三, 二反田博之. 縦隔腫瘍と術前診断された肺過誤腫の 1 例. 日臨外会誌 2010; 71: 2851-4.

\title{
A case of pulmonary hamartoma preoperatively diagnosed as a mediastinal tumor
}

\author{
Ryotaro Kamohara, Mitsutoshi Ishii, Daisuke Taniguchi, Akihiro Nakamura \\ Department of Chest Surgery, Sasebo City General Hospital
}

A 76-year-old man had an abnormal shadow on chest radiograph. Chest CT and MRI showed a mass of $6 \mathrm{~cm}$ in diameter, with calcifications and areas of fat attenuation within it. An axial view showed a well-defined mass between the mediastinum and right lung with an extrapleural sign. A mediastinal teratoma was suspected. Thoracotomy revealed a protruded mass lesion from the right lower lobe. Right lower lobectomy was performed. On histological analysis, a pulmonary hamartoma was diagnosed. 